\title{
Research on Innovative and Entrepreneurial Talents Education of Design in Colleges and Universities Under the Development of Cultural and Creative Industry*
}

\author{
Bailin Xiao \\ Northeast Electric Power University \\ Jilin, China
}

\begin{abstract}
As an important category of cultural and creative industries, design has a more urgent need for creative talents with innovative thinking and entrepreneurial ability. It has positive significance to explore the educational approaches of creative and entrepreneurial talents in designing disciplines for strengthening the talents of cultural and creative industries in our country and promoting the comprehensive reform of innovative and entrepreneurial education in colleges and universities. Design itself contains a sense of innovation and potential entrepreneurial behavior. The education of creative and entrepreneurial talents in design major not only emphasizes the cultivation of students' creative thinking, aesthetic ability, abstract thinking ability, etc, but also should be paid more attention to cultivating students' ability to develop new thinking, explore new methods, integrate interdisciplinary knowledge to find problems, analyze problems, solve problems, and transform them into entrepreneurial abilities, with lifelong entrepreneurial consciousness and entrepreneurial spirit.
\end{abstract}

Keywords-cultural and creative industry; innovative consciousness; entrepreneurial ability

\section{INTRODUCTION}

Cultural and creative industry is an industry that emphasizes a subject culture or cultural factors that rely on individuals (teams) to develop and market intellectual property rights by means of technology, creativity and industrialization. The essence of cultural and creative industry is a kind of "creative economy". Its core lies in human's creativity and exerting human's creativity to the maximum extent. "Differentiation" and "individuation" inspired by originality are the foundation and life of "cultural creative industry". At present, the economy of our country has changed from the stage of high speed growth to the stage of high quality development, which puts forward new and higher requirements for the promotion of mass entrepreneurship and innovation. As an important category in the cultural and creative industries,

*[Project source]: This paper is the general planning subject of the "13th Five-year Plan" of Jilin Province Educational Science: the research result of "mass entrepreneurship and innovation" talent training model of visual communication design major in colleges and universities, the research results of GH170359. the design discipline has a more urgent need for creative talents with innovative thinking and entrepreneurial ability. For the design education of colleges and universities, it has positive significance to explore the ways of creative talents education in design disciplines, to strengthen the talents of cultural and creative industries in China and to promote the comprehensive reform of innovation and entrepreneurship education in colleges and universities.

\section{THE NECESSITY OF RESEARCH ON INNOVATION AND} ENTREPRENEURSHIP EDUCATION OF DESIGN IN COLLEGES AND UNIVERSITIES

Since the Ministry of Education started the pilot work of innovative entrepreneurship education in 9 universities such as Qinghua University in 2002, after more than 10 years of development, colleges and universities in China have gradually formed a group of unique innovative entrepreneurship education system and entrepreneurial talent training system. The official release of the "opinions on the implementation of the Reform of Innovation and Entrepreneurship Education in Colleges and Universities" issued by the General Office of the State Council in 2015 raised innovative entrepreneurship education to the height of the national and national development strategies. The guiding ideology, basic principles and general objectives of deepening the reform of innovative entrepreneurship education in colleges and universities are specified, which indicates that the innovative entrepreneurship education in colleges and universities in China has entered a stage of rapid development.

According to the latest issued by the Ministry of Education, "undergraduate Specialty catalogue of ordinary Colleges and Universities", The major subjects of design in colleges and universities in China include visual communication design, environmental design, clothing and clothing design, digital media art, art design, product design, public art, art design, art and science and technology. As a creative activity, design itself contains innovative consciousness and potential entrepreneurial behavior. The education of creative and entrepreneurial talents in design major not only emphasizes the cultivation of students creative thinking, aesthetic ability and abstract thinking ability, 
but also focuses on cultivating students to develop new thinking, explore new methods, and integrate interdisciplinary knowledge to find problems. Analyze the problem, solve the problem, and transform it into entrepreneurial ability, have lifelong entrepreneurial consciousness and entrepreneurial spirit. The innovative entrepreneurship education in China is in the stage of exploration and development, especially the innovative entrepreneurship education of the design specialty still has many shortcomings. For example, the main focus on the transfer of professional knowledge, skills learning and employment, has not risen to pay attention to the needs of individual development of students and the training of highquality talents. The course of entrepreneurial knowledge is out of touch with the professional curriculum, and most of them remain at the level of theory teaching, innovation and practice projects and lack of platform for entrepreneurial practice.

\section{THE RESEARCH PATH OF INNOVATION AND ENTREPRENEURSHIP EDUCATION FOR DESIGN MAJOR IN UNIVERSITIES}

\section{A. Defining the Logical Orientation of Designing and Innovating the Education of Entrepreneurial Talents}

The essence of innovative entrepreneurship education is a kind of educational theory, educational mechanism and educational practice, which takes cultivating students' innovative spirit, entrepreneurial consciousness and entrepreneurial ability as the basic value orientation. The education of creative and entrepreneurial talents in design major mainly includes two aspects: on the one hand, the construction of students' innovative consciousness and thinking, and on the other hand, the cultivation of students' ability to innovate and set up business. From the logical level, "innovative entrepreneurship" is the logical starting point for the cultivation of design talents, which includes stimulating and cultivating students' strong motivation for knowledge, exploring spirit, innovative thinking, and promoting their ability to find the entrepreneurial opportunities, grasp the changing trends of the market and allocate resources reasonably. "Education" is the logical focus of talent training in design. Both the cultivation of innovative thinking and the promotion of entrepreneurial ability should be realized through systematic and systematic education. In short, "innovation and entrepreneurship" and "education" are the basic attributes of talent education in designing innovation and entrepreneurship. To improve the effectiveness of education is the key logical orientation of innovative design and entrepreneurship education.

\section{B. Setting up the Goal of Training the Ability of Talents in Designe, Innovation and Entrepreneurship}

Innovation and entrepreneurship education lies in emphasizing the innovative consciousness, spirit and ability of education, teaching and training of talents, and the ability to transform this innovative ability into self-value realization (entrepreneurial ability) in the environment of social and economic development. The ability of creative and entrepreneurial talents in design major is first reflected in the level of knowledge structure, which requires students to have a broad knowledge base of humanities and social disciplines, good artistic accomplishment and solid professional design ability. Be familiar with the diversified theoretical knowledge of the design discipline and its related marginal disciplines, and apply it to the practice of design creation. At the level of intelligent structure, it is necessary for the students to have the ability of creative thinking and exploration, to understand the professional theory knowledge thoroughly, and to integrate it with the professional practice. In addition, students should also have the ability to collect information, query information, autonomous learning and problem-solving. At the level of quality requirements, students are required to establish a correct world outlook and outlook on life, cultivate a good sense of social responsibility, a keen sense of market economy, and the ability of systematic design and management.

\section{Perfecting the Curriculum System of Talents Education in Designe, Innovation and Entrepreneurship}

Curriculum system construction is the foundation of innovative entrepreneurship education. The teaching of design major has the characteristics of comprehensiveness, diversity, creativity and practicality. The research of traditional design education is mainly focused on the innovative research on the micro level of the specialty, and on the cultivation of innovative thinking in solving a certain project or problem. However, there is a lack of research on the overall development of innovative entrepreneurship education and the combination of the design of professional training system and mechanism. How to improve the professional and technical ability of students majoring in design, how to cultivate entrepreneurial consciousness, entrepreneurial knowledge, entrepreneurial ability and entrepreneurial quality on the basis of entrepreneurial practice, so as to achieve the unity of the content of design entrepreneurship education and the goal of innovative entrepreneurship education, etc. It is necessary to explore the course system of design specialty and perfect the curriculum system of designing and innovating talents for entrepreneurship education.

First of all, in the course system, it is necessary to achieve the blending of curriculum plan, promote the proportion of inter discipline hours, expand the interdisciplinary vision and enlighten students to solve problems from an innovative perspective according to the design of innovative talents training goals. The American Association of higher Education Research points out that it is the best way to accept the mode of interdisciplinary entrepreneurship education. That is to say, to cultivate entrepreneurial ability is not to deviate from the subject course, but to reconstruct the subject teaching process.

Secondly, we should focus on the core curriculum system of design major, set up special courses for different types of research and development training of design and entrepreneurship projects, and integrate innovative ideas of entrepreneurship education into professional curriculum education. Ensure innovation and entrepreneurship education throughout the undergraduate learning phase. On the one hand, the setting of professional curriculum should accord with the long-term goal of the subject development plan, on the other hand, it should also adapt to the overall goal of national and regional economic development. 
Finally, in the aspect of elective courses, we should set up cross-disciplinary platform courses, set up an internal network of cross-border courses, increase the intensity of elective courses, and enable students to rely on a professional foundation, which is able to get a strong comprehensive interdisciplinary training, highlight the characteristics of the interdisciplinary curriculum system.

\section{Improving the Training System of the Practical Ability of Talents in Design, Innovation and Entrepreneurship}

The ability of practical application is the ability to use theoretical knowledge to solve practical problems, while the ability of innovation and entrepreneurship is rooted in practice. Innovation is the foundation of entrepreneurship. The practical activities of innovation and entrepreneurship should be closely combined with the advantages of discipline and social needs in both carrier and content. The cultivation of creative talents should focus on cultural entrepreneurship and solve problems through team interdisciplinary cooperation. According to the progressive principle of ability training, combining with the inherent relationship and characteristics of practical ability, innovation ability and entrepreneurial ability, the training system of innovative entrepreneurship practice for major students is mainly divided into the stage of professional practical ability training, innovation ability training stage and entrepreneurial ability incubation stage.

First of all, in the training stage of professional practice ability, through professional cognitive practice, curriculum design, research practice of special projects and in-school design competition activities as the carrier, Through the design of progressive practical curriculum system, students can cultivate creative and innovative design thinking in the process of practice from the beginning of professional education, so as to enhance the basic practical application ability and promote students' ability to develop the combination of entrepreneurship and professional courses.

Secondly, in the stage of cultivation of innovation ability, a system of fostering innovation ability is established, which takes subject competition, college students' innovation plan and graduation design as the main line. Discipline competition is to participate in high-level design competition as a means, using team cooperation, echelon management and other ways to build a pyramid system of discipline competition; As an important carrier of innovative activities for undergraduates at present, the innovative plan of college students promotes students to participate in innovative practice by means of project cultivation, progressive project support and so on. Through the practice of graduation design, the training system of innovative practical ability based on graduation design is formed.

Finally, in the incubating stage of entrepreneurial ability, through the establishment of the cultural creation, production, learning and research center, the design service network platform and the cultural entrepreneurship accelerator, relying on outstanding talent resources, education resources, financial resources, network resources and innovative resources, Focusing on enhancing the thinking and ability of entrepreneurs or entrepreneurial teams, it provides deep integration services including entrepreneurial $R \quad \& \quad D$, entrepreneurial design, resource allocation and business model innovation. Institutions of higher learning and social literacy enterprises jointly set up a platform for entrepreneurial practice, such as cultural and creative parks, creative workshops, and so on. Students can declare their own entrepreneurial projects, establish projects and receive financial assistance.

\section{E. Establishing the Examination and Evaluation System of Talents Education in Design, Innovation and Entrepreneurship}

The core elements of innovation can be divided into ability, personality, cognitive style and thinking strategy. Design and innovation education pays more attention to the cultivation of students' innovative ability, multidimensional cognition and creative practice. Therefore, the assessment of innovative entrepreneurship should also be a multi-perspective comprehensive evaluation, and it is necessary to increase the assessment link of innovative entrepreneurship education on the basis of the existing assessment and evaluation mechanism. First of all, the main body of assessment should be changed from a single subject based on teachers to a pluralistic subject composed of teachers, design project principals, students and students themselves. On the one hand, the diversification of evaluation subjects can improve the reliability and scientific nature of the evaluation results, on the other hand, it can also improve the enthusiasm of students to participate in practical projects and promote the germination of innovative industry consciousness. Secondly, the evaluation method is more dynamic, from the summative evaluation which pays attention to the design result to the dynamic evaluation which pays attention to the development process of design thinking and the formation of innovation ability. This is helpful for teachers to understand students' learning dynamics timely and accurately, to improve teaching methods in real time, and to complete teaching objectives. Finally, the evaluation content should be more reasonable. At present, the content of professional assessment focuses on students' professional ability, while the proportion of examination on students' ability to innovate is relatively low. The examination of innovation and entrepreneurship education should pay equal attention to both professional ability and innovation ability. This is more conducive to the learning of students' independent innovation ability.

\section{F. Strengthening the Construction of Teachers Team in Design, Innovation and Entrepreneurship}

At present, most of the innovative and entrepreneurial teachers in colleges and universities in China are teachers, counselors, league committee members and the staff of the employment department, which are lack of effective professional pertinence and depth of study. Professional teachers focus on professional learning and lack mature and efficient practice and entrepreneurial experience, so it is difficult to form a high-quality teaching team. The cultivation of creative talents of design and innovation not only depends on the opening of entrepreneurship courses and the construction of entrepreneurial platforms, but also the construction of diversified teachers of innovative 
entrepreneurship is the most important for the cultivation of talents. On the one hand, it is necessary to establish a long-term mechanism for the training of entrepreneurial teachers, and to strengthen the training of entrepreneurial teachers through regular training and further education. Full-time entrepreneurial teachers are the main force of entrepreneurship education in colleges and universities. In order to train excellent teachers, we must base ourselves on the in-depth education of teachers in our school and promote the endogenous development of entrepreneurship education. On the other hand, professional teachers are encouraged to actively participate in entrepreneurial practice. Through the establishment of design studios, creative studios and other innovative entrepreneurial teams, or with related industries, enterprises to build collaborative teams, while strengthening the practical ability of professional teachers and entrepreneurial ability, we must make a socially-oriented and market-oriented combination of production, learning and research. At the same time, colleges and universities should also strengthen the introduction of excellent teachers to society, actively explore and design industries, enterprises, creative training institutions and excellent cultural and creative entrepreneurs, and attract experts and scholars who have made achievements in the field of cultural and creative industries. Successful personages and entrepreneurs serve as part-time tutors of entrepreneurship. Through holding training and lectures, they exchange innovative entrepreneurial experiences, provide guidance and help for students in entrepreneurial practice, and enrich students' entrepreneurial knowledge.

\section{CONCLUSION}

"Deepening the reform of innovation and entrepreneurship education in colleges and universities is an urgent need for the country to implement the innovation-driven development strategy and promote the upgrading of economic quality and efficiency, as well as to promote the comprehensive reform of higher education. The important measure of promoting higher quality entrepreneurial employment for college graduates." Innovation and entrepreneurship education in colleges and universities is not only universal, but also subject specific. The exploration of creative and entrepreneurial talents education for design majors is helpful to improve the overall employment quality and comprehensive quality of design students, and to improve the re-learning ability of design major students, adapt to social competition, employment and entrepreneurial ability. It has great practical significance. In this paper, the research path of innovative entrepreneurship education for the design major in colleges and universities provides a certain way of thinking on how to deal with the new trend of the development of higher education in China's colleges and universities, and it is still necessary to carry out in-depth exploration and research in combination with the development plans of different colleges and universities.

\section{REFERENCES}

[1] Fu Zhiyong. From interdisciplinary intersection to open innovation talent training [J]. Decoration, 2014 (12): 14-16. (in Chinese)
[2] Zhao Dandan. How to cultivate talents of Art Design in Colleges and Universities [J]. Art and Technology, 2013 (9). (in Chinese)

Cui Yihu, Guo Wan Niu, Chen Tongyang. The mode and development of individualized cultivation of innovative and entrepreneurial talents in colleges and universities [J]. Educational Exploration, 2016 (12): 61-64. (in Chinese) 